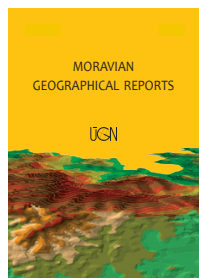

MORAVIAN GEOGRAPHICAL REPORTS

\title{
Teenage overweight and obesity: A pilot study of obesogenic and obesoprotective environments in the Czech Republic
}

\author{
Jana SPILKOVÁ a*
}

\begin{abstract}
Child overweight and obesity represent a serious health problem worldwide. The Czech Republic now ranks the fourth most obese country in Europe and obesity and overweight is becoming more and more frequent in children and teenagers. This pilot study estimates the prevalence of obesity and overweight among Czech teenagers aged 14-15 years in terms of neighbourhood characteristics, and assesses the effects of neighbourhood environmental quality versus family or personal-level factors on teenage obesity and overweight. The results show that unsafe environments result in the risk of lesser physical activity of their inhabitants, but since the vast majority (92\%) of the students felt safe in their neighbourhoods, mediation through safety of the neighbourhood is not at stake. Second, the housing estates demonstrate the most severe problems with both obesity and overweight and their built environments, but when perceptions of sporting facilities and similar opportunities for physical activity are factored in, they do not have low scores; therefore, mediation by physical activity is not a relevant response to the obesity problem. These findings imply that the most important obesogenic and obesoprotective factors are likely to be found within the family environment and personal life styles.
\end{abstract}

Keywords: teenagers, obesity, overweight, neighbourhood, Czech Republic

Article history: Received 30 July 2015; Accepted 10 March 2016; Published 31 March 2016

\section{Introduction}

Child overweight and obesity represent a serious health problem worldwide. A high prevalence of child obesity is no longer only a problem in the USA and other developed countries, as problems with child obesity are often reported from developing countries, as well as from the so-called transition countries of Central and Eastern Europe. The Czech Republic, one of the latter countries, used to rank among the countries with a high prevalence of obesity in adults (Hainer et al., 1999), but even at the beginning of this century the situation with child obesity and overweight was not critical (Kobzová et al., 2004). This started to change rapidly, however, and the Czech Republic is now the fourth most obese country in Europe (measured by adult obesity) and obesity is a major health issue for the Czech population. What is more, obesity and overweight is becoming more and more frequent in children too, mainly among boys. Recently, the Czech Ministry of Health presented the National Health Strategy 2020 focusing on 16 main topics developed into action plans. The fight against obesity and overweight is among the most important of these, because obesity is an epidemic with negative outcomes for an individual's health - it increases the risk of hypertension about six-fold and the risk of diabetes about seven-fold. There will be about one million Czechs with diabetes as a consequence of overweight in the next ten years. Research into obesity and overweight and their prevention among children and adults is thus a national health policy priority.

\section{Theoretical frameworks}

The spread of the obesity epidemic worldwide has been a catalyst for a myriad of studies investigating the linkages between the risk of overweight/obesity and various factors. These factors include both individual (genetic conditions, life style, socioeconomic status, ethnicity, gender) and contextual variables. At the contextual level, the effects of a multi-dimensional environment may contribute to obesity or overweight, including the effects of the home environment and parents' influences on diet and physical activity, the broader social environment and the physical environment of the neighbourhood where a person lives. The issue of the geographic factors, especially built environment and its influence on obesity, has attracted significant attention,

\footnotetext{
${ }^{a}$ Department of Social Geography and Regional Development, Faculty of Science, Charles University in Prague, Czech Republic (*corresponding author: J. Spilková, email: spilkova@natur.cuni.cz)
} 
pointing to the evidence that there are some environments which seem to be more obesogenic than others. The built environment encompasses all human-made infrastructure and resources supporting human activity (building, transport infrastructure, parks, stores, service facilities, etc.) (Davis et al., 2005). The implications for interactions between public health policies and urban design have been established in this field of research, involving many disciplines such as urban planning, landscape architecture, geography, economics, epidemiology, sociology, nutrition science, etc.

As Ding and Gebel (2012) indicate, since the beginning of the millennium, research on the built environment and obesity has skyrocketed and critical literature reviews help to summarize the results in this area. There are a number of quality literature reviews (and also reviews of reviews, such as de Vet et al., 2011, Gebel et al., 2007, Ding and Gebel, 2012) on the influence of the built environment on obesity. Booth et al. (2005) presented one of the first reviews based on nine pioneering studies: they stressed the neighbourhood influences, mainly the effect of safer neighbourhoods which often result in more physical activity and less obesity; lower socioeconomic status, which often leads to less physical activity; the walkability of a neighbourhood and more available physical activity resources; and the land-use mix within the neighbourhood, which usually increases physical activity. Their study has an important methodological implication as it concludes that neighbourhood-level analysis is more representative of the daily lifestyles of residents than the metropolitan level, consisting of many counties with varying built environments (Booth et al., 2005, p. 114). Similar to this methodological note, Panter and Jones (2010) suggest that environments outside the home neighbourhood where individuals spend most of their time should also be studied. In compliance with this guideline, both the home and the school environments have been appraised in this paper.

Another review by Black and Macinko (2008) summarizes the literature on neighbourhood determinants of obesity since 2004, when the majority of articles began to appear. Three elements of built environments appear in these studies: urban design and the physical appearance of public spaces; land use, mainly the density of residential and other activities; and transportation systems, the availability of sidewalks, bike paths, etc. The neighbourhood contextual environment in other studies has also included access to sport and leisure facilities, green space and the degree of urbanization, the perceived safety of the neighbourhood, its general attractiveness, and social capital or social support within the community. This review is worthy to mention in the context of this paper because one of the important results is that the authors found that the bulk of the literature focuses on urban neighbourhoods in high-income countries. The current paper thus also aims to fill this gap by focusing on the Czech Republic - a region where very little information about the obesogenic and obesoprotective environments is available.

A more recent review by Feng et al. (2010) presents a systematic and quantitative assessment of an up-dated body of literature (22 context-based and 15 geographic buffer papers). The selected papers evaluated three domains of the built environment: the physical activity, land use and transportation, and food environments. The authors conclude that although it has become increasingly common to attribute obesity to characteristics of the built environment, existing evidence did not identify a clear and strong role for the built environment. The heterogeneity of the studies limits their comparability and any findings of systematic evidence.

In a similar vein, another review by Durand et al. (2011) studied built environment factors related to physical activity and obesity risk in relation to planning implications, including the so-called "smart growth" principles. These principles in the surveyed studies included a range of housing opportunities and choices, walkable neighbourhoods, communities with a sense of place, mixed land uses, open space and critical environmental areas, a variety of transportation choices, community-oriented development and compact building design. When quantifying the results of the surveyed studies, nevertheless, few studies reported significant associations between the above-mentioned principles and physical activity or the body mass index. These authors concluded that the almost exclusively nonsignificant results here were not surprising since the majority of the studies were cross-sectional, and therefore they anticipated that there are many important factors on other levels which remain unmeasured (such as eating behaviours, etc.).

A slightly more recent review of literature examining the relationship between built environment (parks, trails, sidewalks) and physical activity or obesity by $\mathrm{O}$. Ferdinand et al. (2012) presented similar results. The majority of the surveyed studies $(89 \%)$ do report a beneficial contribution to physical activity and health, but since these papers utilized simple observational study designs, they are not suited for determining causality. Based on this extensive review of the literature, this paper aims to use knowledge stemming mainly from U.S. research reports for a pioneering study analysing the built environment and neighbourhood effects on obesity in the context of a post-socialist country. Literature reviews helped to focus interest on the most commonly-used variables describing various facets of the built environment for this paper's analysis. Furthermore, the micro-geographic level has also been incorporated (quality of the home and school environment, sport facilities, etc.) following the suggestions of Brownson et al. (2009, in Ding and Gebel, 2012), as an audit of the "details" in the quality of the environment and various amenities at a microscale. Similarly, the hypothesis that the linkage between the built environment and obesity varies in different geographic settings (type of neighbourhood, metropolitan versus nonmetropolitan) has been tested. Still, in the post-socialist context, many specific elements may apply.

The post-socialist countries have experienced a dramatic process of transformation and democratization since the beginning of the 1990s. The democratisation of society and the introduction of meritocratic principles and economic freedom, however, have had some negative consequences, e.g. a steep increase in criminality, xenophobia and other socio-pathological phenomena. Structural changes and steep price rises lowered the standard of living in some households, whereas other households, on the contrary, profited from the free market economy and the reestablishment of property rights.

In the Czech Republic, the health behaviours of many people changed due to higher stress related to the need to adapt to new conditions, resulting in an even higher prevalence of alcohol consumption, smoking and drug use and unhealthy lifestyles in general. Secondly, the neighbourhood influence is not as clearly pronounced as 
in the U.S. studies, where racial, socio-economic and even religious heterogeneity correlate with the specific features of neighbourhoods (Janssen et al., 2006; Lopez, 2007; Story et al., 2002; van Lenthe and Mackenbach, 2002, etc. $)^{1}$. The typical housing estates from the communist era with their concrete blocks of flats, housed a wide spectrum of resident classes from manual or blue collar workers to the intelligentsia and elites (Enyedi, 1998; Herfert et al., 2013; Kährik and Tammaru, 2010; Musil, 1987). Even today, these estates accommodate a socio-economic mixture of residents. The same is true for suburbia, which accommodates both new suburbanites in luxurious family houses and the former dwellers, with a different socio-economic profile.

This paper presents a pilot study of several diverse effects on teenage overweight and obesity, taking into account facets of the built environment (the existence of playgrounds, recreational space, adequate housing, etc.), social capital (perceived neighbourhood safety, behaviour norms, area deprivation), family background (economic status, social status), and individual behaviours (physical activity, walking activities) that are thought to influence overweight and/or obesity. There are two broad objectives:

- to estimate the prevalence of obesity and overweight among Czech teenagers aged 14-15 years, using a variety of neighbourhood and built environment characteristics; and

- to assess the effects of neighbourhood environment quality versus the family or personal level influences on teenage obesity and overweight.

\section{Methods}

\subsection{Data collection}

The data for this pilot study came from an on-line survey among elementary school students ( $9^{\text {th }}$ grade), which was administered in 38 selected schools in the Czech Republic, between October 2013 and March 2014. The schools were selected by a purpose-built sampling frame (Dzúrová et al., 2015): First, the schools in Prague were classified for the survey according to their neighbourhood type so that they represented different built environments. The seven built environments included blocks of flats in housing estates, new family houses in suburban areas, row houses, old city apartment houses, newer apartment houses, family houses and semi-detached houses, etc. Second, the schools outside Prague were selected based on their previous results in the ESPAD (The European School Survey on Alcohol and Other Drugs survey). Schools differed according to the trend of their health risk behaviour development - four types of trends were selected: improving, problematic, stable but good, and stable but bad. The Directors of the selected schools representing each trend type were contacted and asked for permission to conduct the survey. The questionnaires were completed in class, usually during lessons of computer education. Students were given a unique code for each school, ensuring the anonymity of individual data. After entering this school-code, the on-line survey form opened and was ready to be filled out. The research process followed the ethical guidelines proposed by the Czech government; thus, all procedures were performed in compliance with the relevant laws and institutional guidelines which appropriate institutional committees have approved.
Only students aged 14-15 years were selected for the analysis. Altogether, 1,025 valid responses were received: $48.5 \%$ of the sample was girls and $51.5 \%$ boys; $39 \%$ of the surveyed students lived in the capital city of Prague and the remaining $61 \%$ in other areas of the country. Most of the students lived in housing estates with blocks of flats (38.2\%), $20.2 \%$ lived in traditional family houses, $18 \%$ lived in newly-built family houses in suburbia, $9.5 \%$ in new apartment houses in outer city areas, $7.2 \%$ in older city apartment houses in inner city neighbourhoods, $4.5 \%$ in row houses and $2.3 \%$ in semi-detached houses.

\subsection{Measures}

The dependent variable for the analysis in this paper was the odds of obesity and overweight defined according to the international sex- and age-specific cut-off points for body mass index of $25 \mathrm{~kg} / \mathrm{m}^{2}$ and $30 \mathrm{~kg} / \mathrm{m}^{2}$. These cut-off points were constructed in order to define child obesity based on the same principle at different ages, based on averaging the reference population of children from a mix of large representative surveys in different countries (Cole et al., 2000). The body mass index (BMI) proved to be one of the most satisfactory indicators of relative obesity (Keys et al., 2014).

Besides the above-mentioned neighbourhood type (with respect to the built environment), other neighbourhood and school environmental factors were the primary independent variables of interest. We use similar characteristics of neighbourhoods to the U.S. studies (Singh et al., 2010). Since the disorder or delinquency issues differ in the USA and the Czech Republic, however, we chose those appropriate for the Czech context. In contrast to the aggregate data, we used the adolescents' own perceptions of their home and school environment to extract subjective measures of the environmental contexts (for the importance of individual perceptions, see, e.g. Winstanley et al., 2008; Pacione, 2003; Weden et al., 2008). These selected characteristics included, for example, signs of violence or vandalism, poor or dilapidated housing, garbage or litter in the neighbourhood, drugs or alcohol consumed on the streets, and racial or religious problems. Built environment factors such as access to parks, greenery, playgrounds and sport facilities, were also assessed in the survey. These items were scored on a scale from 1 to 4 points, coded as $1=$ no problem, $2=$ small problem, $3=$ bigger problem, $4=$ serious problem, so that the higher scores indicated a greater degree of neighbourhood disadvantage. Last, neighbourhood safety was based on the question, "Do you feel safe and secure in the area of your home: never, sometimes, usually or always?".

A second important group of variables was presented by determinants of behavioural factors with potential effects on obesity, such as physical activity (at school, at home, with friends, specialized training etc.), and the student's mode of transportation to school (both changed to binary variables for the analysis). The last group of variables covered individual and family demographic and socio-economic characteristics such as age, gender, family affluence (below average, average, above average), education of parents (elementary school, secondary school, university degree), etc.

\subsection{Statistical analysis}

The date were transferred into a database and analysed statistically using SPSS (Statistical Package for the Social

\footnotetext{
${ }^{1}$ As regards ethnic and religious heterogeneity, the Czech Republic is rather homogenous (70\% ethnic Czechs, $89 \%$ Czechspeaking) and mostly atheist (34.2\% without religion) (Czech Statistical Office, 2011).
} 
Sciences), version 17 (SPSS, Chicago, IL). First, descriptive analyses were conducted to explore the character of the data and their basic distributions (SPSS command Analyze Descriptive Statistics). Second, contingency analyses (chi-square statistics) were applied to test the overall associations between the covariates (SPSS command Analyze - Descriptive Statistics - Crosstabs). Subsequently, logistic regression models were used to estimate the odds of obesity and overweight in the sample of Czech teenagers. The dependent variable was defined as binary (underweight or normal weight coded as 0 , versus overweight and/or obese coded as 1). Next, logistic regression models were conducted to examine the effects of the particular factors (SPSS command Analyze - Regression - Binary Logistic). A three-level data structure was applied in the logistic regression models: the environmental level (1); the family level (2); and the personal level (3) which has entered into the analysis as individual blocks of variables. Thus, a multilevel model was used, but the data structure has to take into account the fact that in some cases, the data were collected for one class in any chosen school, which likely means that the data will be clustered, i.e., there is a withinclass correlation of responses.

\section{Results}

The prevalence of overweight and obesity in this study is depicted in Tab. 1. Altogether, 17.2\% teenagers were overweight and $3.8 \%$ were obese. At the age of 14-15 years, boys were more likely to be both overweight $(20.8 \%$ overweight boys versus $13.3 \%$ girls) and obese $(4.7 \%$ versus $2.8 \%$ ). The results show that there are significant gender differences for overweight (chi-square $=10.27$, $\mathrm{p}=0.001$ ) but not for obesity (chi-square $=2.57, \mathrm{p}=0.109$ ).

As regards the type of neighbourhood (Tab. 2), the highest prevalence of overweight and obese teenagers was found in the neighbourhoods with row houses $(26.1 \%$ and $6.6 \%$ respectively), followed by teenagers living in housing estates with blocks of flats $(19.1 \%$, and $4.3 \%)$, however, the differences are not statistically significant. Chi-square analysis of the Tab. 2 shows Overweight: chi-square $=7.47$, $\mathrm{p}=0.29$; Obese: chi-square $=1.78, \mathrm{p}=0.939$, but table has too many cells with expected frequencies less than 5 for the association to be tested properly.

The exploratory data analyses further show that the majority of students came from average income families $(60.4 \%), 29.1 \%$ rated their family as above average (somewhat

\begin{tabular}{|c|c|c|c|c|c|c|c|c|}
\hline & & & \multicolumn{3}{|c|}{ Overweight } & \multicolumn{3}{|c|}{ Obesity } \\
\hline & & & no overweight & overweight & total & no obesity & obesity & total \\
\hline \multirow[t]{4}{*}{ gender } & Girl & Count & 431 & 66 & 497 & 483 & 14 & 497 \\
\hline & & $\%$ within gender & $86.7 \%$ & $13.3 \%$ & $100 \%$ & $97.2 \%$ & $2.8 \%$ & $100 \%$ \\
\hline & Boy & Count & 418 & 110 & 528 & 503 & 25 & 528 \\
\hline & & $\%$ within gender & $79.2 \%$ & $20.8 \%$ & $100 \%$ & $95.3 \%$ & $4.7 \%$ & $100 \%$ \\
\hline \multirow[t]{2}{*}{ Total } & & Count & 849 & 176 & 1,025 & 986 & 39 & 1,025 \\
\hline & & $\%$ within gender & $82.8 \%$ & $17.2 \%$ & $100 \%$ & $96.2 \%$ & $3.8 \%$ & $100 \%$ \\
\hline
\end{tabular}

Tab. 1: Prevalence of overweight and obesity among ninth-grade students. Source: author's calculations

\begin{tabular}{|c|c|c|c|c|c|c|c|}
\hline & & \multicolumn{3}{|c|}{ Overweight } & \multicolumn{3}{|c|}{ Obesity } \\
\hline & & no overweight & overweight & total & no obesity & obesity & total \\
\hline \multirow[t]{2}{*}{ block of flats } & Count & 317 & 75 & 392 & 375 & 17 & 392 \\
\hline & $\%$ within neighbourhood & $80.9 \%$ & $19.1 \%$ & $100 \%$ & $95.7 \%$ & $4.3 \%$ & $100 \%$ \\
\hline \multirow{2}{*}{$\begin{array}{l}\text { new family } \\
\text { house }\end{array}$} & Count & 156 & 29 & 185 & 178 & 7 & 185 \\
\hline & $\%$ within neighbourhood & $84.3 \%$ & $15.7 \%$ & $100 \%$ & $96.2 \%$ & $3.8 \%$ & $100 \%$ \\
\hline \multirow[t]{2}{*}{ row house } & Count & 34 & 12 & 46 & 43 & 3 & 46 \\
\hline & $\%$ within neighbourhood & $73.9 \%$ & $26.1 \%$ & $100 \%$ & $93.5 \%$ & $6.5 \%$ & $100 \%$ \\
\hline \multirow{2}{*}{$\begin{array}{l}\text { older city } \\
\text { apartment } \\
\text { house }\end{array}$} & Count & 63 & 11 & 74 & 71 & 3 & 74 \\
\hline & $\%$ within neighbourhood & $85.1 \%$ & $14.9 \%$ & $100 \%$ & $95.9 \%$ & $4.1 \%$ & $100 \%$ \\
\hline \multirow{2}{*}{$\begin{array}{l}\text { newer apart- } \\
\text { ment house }\end{array}$} & Count & 82 & 15 & 97 & 94 & 3 & 97 \\
\hline & $\%$ within neighbourhood & $84.5 \%$ & $15.5 \%$ & $100 \%$ & $96.9 \%$ & $3.1 \%$ & $100 \%$ \\
\hline \multirow{2}{*}{$\begin{array}{l}\text { older family } \\
\text { house }\end{array}$} & Count & 174 & 33 & 207 & 201 & 6 & 207 \\
\hline & $\%$ within neighbourhood & $84.1 \%$ & $15.9 \%$ & $100 \%$ & $97.1 \%$ & $2.9 \%$ & $100 \%$ \\
\hline \multirow{2}{*}{$\begin{array}{l}\text { semi-detached } \\
\text { house }\end{array}$} & Count & 23 & 1 & 24 & 24 & 0 & 24 \\
\hline & $\%$ within neighbourhood & $95.8 \%$ & $4.2 \%$ & $100 \%$ & $100.0 \%$ & $0.0 \%$ & $100 \%$ \\
\hline \multirow[t]{2}{*}{ Total } & Count & 849 & 176 & 1,025 & 986 & 39 & 1,025 \\
\hline & $\%$ within neighbourhood & $82.8 \%$ & $17.2 \%$ & $100.0 \%$ & $96.2 \%$ & $3.8 \%$ & $100.0 \%$ \\
\hline
\end{tabular}

Tab. 2: Prevalence of overweight and obesity according to neighbourhood type Source: author's calculations 
rich and very rich), and $10.5 \%$ came from families with lower than average income. Teenagers reported doing vigorous physical exercise alone or with friends $(57.3 \%$ and $53.4 \%$ respectively), $16.6 \%$ participated in sports teams and $29.5 \%$ reported some professional training. Surprisingly, the majority of the children (82.1\%) said they did not take part in school physical education. As for transportation, 53.5\% of respondents walked to school and $38 \%$ used public transport, while only $0.5 \%$ cycled to school. The remaining $8.1 \%$ used car, motorcycle or other means of transport.

The vast majority of responding teenagers evaluated their neighbourhood as safe ('always safe' $45.9 \%$, or 'most of the time safe' $46.2 \%$ ), $6.6 \%$ felt safe in the vicinity of their homes only sometimes, and just $1.3 \%$ of the surveyed teenagers responded that they never felt safe in their neighbourhood. As regards particular problems of the built environment, in average drug and alcohol consumption around schools, violence and vandalism, and garbage or litter around schools have been often mentioned as a large problem (17.3\%, respectively, $14.9 \%$ and $12.6 \%$ ), as well as drugs and alcohol consumed around home $(13.2 \%$, a serious problem), dilapidated neighbourhoods, litter in the streets, etc. around home (10.7\%), and vandalism, violence and crime in the home neighbourhood (10.1\%)

The inhabitants of particular neighbourhoods differed significantly in their health behaviours (physical activity, transportation to school) and in their assessments of the qualities of built environment characteristics. Teenagers living in unsafe neighbourhoods were significantly the most likely to be physically inactive $(\mathrm{C}=0.123, \mathrm{p}<0.001)^{2}$. The same is true for those teenagers who reported that they perceive violence and vandalism in their home neighbourhood as a serious problem $(\mathrm{C}=0.102, \mathrm{p}<0.05)$. Even stronger is the consequence of negative perceptions of the school environment and physical activity: those students who criticize the racial, religious or ethnic disorder around their schools were those who were physically inactive $(C=0.100, p<0.05)$, and the same applies to those who perceive the consumption of drugs in the vicinity of their school as a serious problem $(\mathrm{C}=0.101, \mathrm{p}<0.05)$. Also, rather important is the revealed relation between the type of the neighbourhood and transportation to school $(\mathrm{C}=0.414, \mathrm{p}<0.001)$ : the children from the housing estates are much more likely to walk to school compared to the children from older and new family houses, as these students are more reliant on public transport. The relation between perceived safety of the neighbourhood and the mode of transport is statistically significant $(\mathrm{C}=0.198$, $\mathrm{p}<0.001$ ), but it brings mixed results.

Rather surprisingly, those living in housing estates were significantly less likely to negatively evaluate the access to sporting facilities of the housing estates' schools, while teenagers from row-houses and older family houses significantly more often evaluated the sporting facilities in their neighbourhood schools as problematic $(\mathrm{C}=0.196$, $\mathrm{p}<0.05$ ). When we turn to characteristics of the built environment around the homes of respondents, the inhabitants of housing estates were significantly less likely to positively evaluate their neighbourhoods and the racial or religious problems, while those living in suburban areas with new family houses are more likely to evaluate these issues positively $(\mathrm{C}=0.220, \mathrm{p}<0.001)$. Exactly the same is the case for the question about violence and vandalism in the neighbourhoods of housing estates and new family houses $(\mathrm{C}=0.198, \mathrm{p}<0.05)$, for the lack of greenery $(\mathrm{C}=0.199, \mathrm{p}<0.05)$, use of drugs and alcohol in public spaces $(C=0.216, p<0.001)$, and overall dilapidation of the neighbourhood $(\mathrm{C}=0.226, \mathrm{p}<0.001)$.

The binary logistic regression models for the measures of teenage overweight and obesity is depicted in the next table. Tab. 3 presents three models which are (1) environmental, (2) family, and (3) personal. It reflects the survey structure by assessing particular levels of the analysis. It showed significant results only for the gender and family affluence explanatory variables. Boys are about 1.6 times more likely to be overweight than girls at the age of $14-15$ years. Teenagers from average affluent families are 2.45 times more likely to be overweight and/or obese than teenagers from more affluent families. Also, teenagers from less affluent families have a higher likelihood of being overweight and/or obese (1.7 times more than those from affluent families). The effects of the built environment of home and school neighbourhoods, the differences between Prague and the rest of the country, or the perceived safety of the neighbourhood were insignificant or mixed, as well as the results for physical activity or means of transport in the second model (Tab. 3).

\section{Discussion}

Despite the fact that our results have not revealed significant associations between built environment characteristics and teenage overweight and/or obesity, as is common for many studies coming from the U.S. or "western" context (Booth et al., 2005; Janssen et al., 2006; Lopez, 2007; van Lenthe and Mackenbach, 2002, etc.), there are many results related to particular covariates of overweight and obesity worth noting in the Czech sample.

Housing estates with blocks of flats seem to be the most problematic type of neighbourhood when considering overweight and obesity, and for many reasons ${ }^{3}$. First, their residents are more likely to suffer from the effects of racial, ethnic or religious disorder, violence and vandalism, use of alcohol and drugs in public spaces, and overall untidiness, garbage and litter in the surroundings of their homes, as well as the overall dilapidation of the houses and whole neighbourhoods. Such environments are perceived as unsafe and, according to our results, this also brings a higher probability of being physically inactive. Similar outcomes were found by Saelens et al. (2003a, b), who showed that safer neighbourhoods with a mixture of functions often result in more physical activity and less overweight and obesity. Similarly depicted by the results of Franzini et al. (2009), it seems that a favourable social environment of the neighbourhood positively influences overall physical activity.

We agree with their findings, although Franzini et al. (2009, p. 275) in their study concluded that the physical environment was not significantly associated with measures of physical activity, because the children get

\footnotetext{
${ }^{2} \mathrm{C}=$ Contingency coefficient: $\sqrt{ }\left[\chi^{2} /\left(\mathrm{N}+\chi^{2}\right)\right]$

${ }^{3}$ Only the built environment of row houses proved to be more obesogenic in our study; however, the sample of teenagers from these neighbourhoods is quite small.
} 


\begin{tabular}{|c|c|c|c|c|c|c|}
\hline & \multicolumn{2}{|c|}{ Model 1} & \multicolumn{2}{|c|}{ Model 2} & \multicolumn{2}{|c|}{ Model 3} \\
\hline & Sig. & $\operatorname{Exp}(B)$ & Sig. & $\operatorname{Exp}(B)$ & Sig. & $\operatorname{Exp}(B)$ \\
\hline \multicolumn{7}{|l|}{ Type of neighbourhood } \\
\hline housing estate & ref & & ref & & ref & \\
\hline new family house & 0.183 & 0.666 & 0.124 & 0.604 & 0.332 & 0.718 \\
\hline row house & 0.716 & 1.181 & 0.723 & 1.176 & 0.567 & 1.309 \\
\hline older apartment house & 0.803 & 0.902 & 0.619 & 0.810 & 0.514 & 0.749 \\
\hline newer apartment house & 0.400 & 0.724 & 0.318 & 0.678 & 0.523 & 0.776 \\
\hline older family house & 0.130 & 0.631 & 0.111 & 0.592 & 0.146 & 0.616 \\
\hline semi-detached house & 0.089 & 0.166 & 0.082 & 0.159 & 0.109 & 0.181 \\
\hline \multicolumn{7}{|c|}{ Prague vs. Non-metropolitan } \\
\hline non-metropolitan & 0.305 & 1.258 & 0.290 & 1.278 & 0.336 & 1.255 \\
\hline \multicolumn{7}{|c|}{ Feeling safe in the neighbourhood } \\
\hline always & ref & & ref & & ref & \\
\hline most of the time & 0.371 & 2.739 & 0.410 & 2.531 & 0.242 & 3.869 \\
\hline sometimes & 0.530 & 2.026 & 0.519 & 2.063 & 0.345 & 2.979 \\
\hline scarcely or never & 0.204 & 4.394 & 0.203 & 4.396 & 0.129 & 6.104 \\
\hline \multicolumn{7}{|c|}{ Perception of racial, ethnic or religious disorders around school } \\
\hline no problem & ref & & ref & & ref & \\
\hline small problem & 0.557 & 1.405 & 0.466 & 1.529 & 0.431 & 1.599 \\
\hline bigger problem & 0.346 & 1.726 & 0.304 & 1.818 & 0.247 & 1.993 \\
\hline serious problem & 0.411 & 1.635 & 0.369 & 1.717 & 0.333 & 1.812 \\
\hline \multicolumn{7}{|c|}{ Perception of litter, rubbish, untidiness around school } \\
\hline no problem & ref & & ref & & ref & \\
\hline small problem & 0.843 & 1.104 & 0.909 & 1.059 & 0.851 & 1.100 \\
\hline bigger problem & 0.346 & 1.514 & 0.359 & 1.498 & 0.307 & 1.582 \\
\hline serious problem & 0.784 & 0.889 & 0.782 & 0.887 & 0.708 & 0.848 \\
\hline \multicolumn{7}{|c|}{ Perception of drug or alcohol use in the public space around school } \\
\hline no problem & ref & & ref & & ref & \\
\hline small problem & 0.201 & 1.819 & 0.176 & 1.888 & 0.210 & 1.814 \\
\hline bigger problem & 0.140 & 1.928 & 0.122 & 1.990 & 0.116 & 2.032 \\
\hline serious problem & 0.521 & 1.336 & 0.464 & 1.395 & 0.460 & 1.406 \\
\hline \multicolumn{7}{|c|}{ Perception of vandalism and dilapidation around school } \\
\hline no problem & ref & & ref & & ref & \\
\hline small problem & 0.591 & 0.748 & 0.579 & 0.740 & 0.455 & 0.664 \\
\hline bigger problem & 0.564 & 0.751 & 0.582 & 0.761 & 0.386 & 0.645 \\
\hline serious problem & 0.998 & 0.999 & 0.984 & 0.990 & 0.875 & 0.925 \\
\hline \multicolumn{7}{|c|}{ Perception of traffic congestions and other traffic problems around school } \\
\hline no problem & ref & & ref & & ref & \\
\hline small problem & 0.338 & 0.608 & 0.394 & 0.638 & 0.262 & 0.547 \\
\hline bigger problem & 0.359 & 0.625 & 0.409 & 0.651 & 0.303 & 0.578 \\
\hline serious problem & 0.828 & 0.890 & 0.889 & 0.927 & 0.737 & 0.830 \\
\hline \multicolumn{7}{|c|}{ Perception of greenery around school } \\
\hline no problem & ref & & ref & & ref & \\
\hline small problem & 0.951 & 1.036 & 0.972 & 1.021 & 0.848 & 0.894 \\
\hline bigger problem & 0.689 & 1.243 & 0.731 & 1.209 & 0.876 & 1.091 \\
\hline serious problem & 0.676 & 1.270 & 0.698 & 1.251 & 0.880 & 1.091 \\
\hline
\end{tabular}

Tab. 3: Binary logistic regression models for teenage overweight and/or obesity. Notes: ref. = reference category; results in bold $=p<0.05$. Model 1 is for the (home and school) environmental factors; Model 2 adds in family characteristics; Model 3, individual characteristics. Source: author's calculations 


\begin{tabular}{|c|c|c|c|c|c|c|}
\hline & \multicolumn{2}{|c|}{ Model 1} & \multicolumn{2}{|c|}{ Model 2} & \multicolumn{2}{|c|}{ Model 3} \\
\hline & Sig. & $\operatorname{Exp}(B)$ & Sig. & $\operatorname{Exp}(B)$ & Sig. & $\operatorname{Exp}(B)$ \\
\hline \multicolumn{7}{|c|}{ Perception of sport facilities around school } \\
\hline no problem & ref & & ref & & ref & \\
\hline small problem & 0.234 & 0.628 & 0.386 & 0.708 & 0.693 & 0.851 \\
\hline bigger problem & 0.100 & 0.520 & 0.206 & 0.599 & 0.423 & 0.718 \\
\hline serious problem & 0.046 & 0.410 & 0.085 & 0.460 & 0.169 & 0.531 \\
\hline \multicolumn{7}{|c|}{ Perception of racial, ethnic or religious disorders around home } \\
\hline no problem & ref & & ref & & ref & \\
\hline small problem & 0.366 & 0.555 & 0.386 & 0.566 & 0.410 & 0.572 \\
\hline bigger problem & 0.259 & 0.475 & 0.301 & 0.503 & 0.352 & 0.529 \\
\hline serious problem & 0.075 & 0.292 & 0.080 & 0.297 & 0.077 & 0.286 \\
\hline \multicolumn{7}{|c|}{ Perception of vandalism and dilapidation around home } \\
\hline no problem & ref & & ref & & ref & \\
\hline small problem & 0.946 & 0.957 & 0.997 & 0.998 & 0.950 & 0.958 \\
\hline bigger problem & 0.770 & 1.198 & 0.722 & 1.250 & 0.691 & 1.284 \\
\hline serious problem & 0.824 & 0.878 & 0.853 & 0.896 & 0.834 & 0.882 \\
\hline \multicolumn{7}{|c|}{ Perception of greenery around home } \\
\hline no problem & ref & & ref & & ref & \\
\hline small problem & 0.371 & 1.759 & 0.436 & 1.635 & 0.318 & 1.914 \\
\hline bigger problem & 0.888 & 1.094 & 0.989 & 1.009 & 0.799 & 1.184 \\
\hline serious problem & 0.469 & 1.562 & 0.552 & 1.443 & 0.336 & 1.841 \\
\hline \multicolumn{7}{|c|}{ Perception of litter, rubbish, untidiness around home } \\
\hline no problem & ref & & ref & & ref & \\
\hline small problem & 0.151 & 0.421 & 0.121 & 0.393 & 0.126 & 0.390 \\
\hline bigger problem & 0.797 & 0.868 & 0.770 & 0.851 & 0.709 & 0.812 \\
\hline serious problem & 0.325 & 1.638 & 0.324 & 1.643 & 0.347 & 1.614 \\
\hline \multicolumn{7}{|c|}{ Perception of drug or alcohol use in the public space around home } \\
\hline no problem & ref & & ref & & ref & \\
\hline small problem & 0.728 & 0.831 & 0.721 & 0.825 & 0.848 & 0.900 \\
\hline bigger problem & 0.201 & 0.518 & 0.167 & 0.486 & 0.173 & 0.488 \\
\hline serious problem & 0.005 & 0.197 & 0.007 & 0.206 & 0.008 & 0.214 \\
\hline \multicolumn{7}{|l|}{ Mother's education } \\
\hline university degree & & & ref & & ref & \\
\hline secondary school & & & 0.631 & 0.771 & 0.658 & 0.787 \\
\hline elementary school & & & 0.467 & 0.825 & 0.539 & 0.849 \\
\hline \multicolumn{7}{|l|}{ Father's education } \\
\hline university degree & & & & & ref & \\
\hline secondary school & & & 0.118 & 2,258 & 0.087 & 2.455 \\
\hline elementary school & & & 0.535 & 1.184 & 0.501 & 1.202 \\
\hline \multicolumn{7}{|c|}{ Economic affluence of the family } \\
\hline above average & & & ref & & ref & \\
\hline average & & & 0.031 & 2.286 & 0.022 & 2.450 \\
\hline below average & & & 0.061 & 1.637 & 0.044 & 1.712 \\
\hline Physically active (y & & & & & 0.586 & 1.267 \\
\hline Transportation to $s$ & active $=$ & & & & 0.526 & 1.171 \\
\hline Gender (girl = ref. $)$ & & & & & 0.029 & 1.627 \\
\hline
\end{tabular}

Tab. 3: continued 
most of their physical exercise in school, gym etc., so that neighbourhood physical characteristics are less relevant. This becomes problematized in our study and its results, which show that the level of physical activity at school is critically low and most of the teenagers who are physically active get the majority of their exercise alone or with friends in their spare time.

There is another paradox related to physical activity and the built environment in the Czech context: as our results show, the teenagers from housing estates (perceived as highly problematic environments) obviously do not suffer from any major lack of sporting facilities around their home or in the schools in their neighbourhoods, and they are also those who are most likely to walk to school. The housing estates were built during the communist era and often represented a challenge for urban planners and architects, who aimed to fulfil the requirements of architectural competitions (Musil, 1985; van Kempen et al., 2009). Therefore, despite the fact that today's housing estates may already be dilapidated or in need of repair and reconstruction, there is a surprisingly large amount of green space and accessible sport facilities both within the school complexes and within the public spaces of these neighbourhoods.

Carrying out this pilot study has turned out to be an important step towards a future research agenda in the realm of obesogenic and obesoprotective environments in the Czech Republic, where we evidently can obtain a more intricate picture. First, it is true that unsafe environments result in the risk of lesser physical activity for their inhabitants, but, on the contrary, the vast majority (92\%) of the students felt safe in their neighbourhoods. Thus, mediation through the safety of the neighbourhood is not at stake. Second, the housing estates demonstrate the most severe problems with both obesity and overweight and their built environment, but when it comes to the perception of the sporting facilities and similar opportunities for physical activity, they were not attributed low scores; moreover, the students from the housing estates are more used to walk to school and back. Therefore, again, mediation by physical activity is not the most relevant response to the obesity problem. This implies that the most important obesogenic and obesoprotective factors 'hide' within the family environment.

\section{Limitations}

There are many limitations to this pilot study and its results should be interpreted cautiously. First, our pilot sample is small, so that its statistical power is limited. Second, the study is based on the self-reported height and weight of teenagers, which may be affected by certain underestimations - under-reporting for weight and overreporting for height (Legleye et al., 2014). The inaccuracies of self-reported weight and height may affect the distribution of overweight and obesity risk in our sample, but the degree of these effects, if any, cannot be determined. Third, we have not studied the health food availability and food choices in the particular neighbourhoods, although these are also very often related to the risk of obesity.

Fourth, the data structure employed in this research is clearly multi-level in nature, i.e., the 'students-in-classes' is a first hierarchical level of responses, such that the student responses will be affected by their shared class location, and hence not independent of other responses. As such, schools would be represented as Level 2 units. A full response to this data structure is to employ a multi-level /mixed model approach. For this pilot study, with relatively few cases per level, we have chosen to employ regular regression estimation methods for the models. Fifth, the results of any statistical analysis do not necessarily imply causality.

\section{Conclusions}

This pilot study contributes to a growing body of research on the covariates of child and teenage overweight and obesity, especially the effects of built environments and neighbourhood characteristics. The findings of this research project, similar to other studies cited in the theoretical background, indicate that teenagers living in unsafe and socio-economically disadvantaged neighbourhoods in a state of dilapidation - housing estates with blocks of flats are at increased risk of overweight and obesity. The effects of contributing factors behind these results, however, do not seem to act in the same way. The majority of children perceived their neighbourhood environment as safe, thus lack of safety does not put Czech children and teenagers at risk of overweight or obesity by discouraging physical activity, as it does in many U.S. studies. Also, the history of Czech housing estate construction is different and these neighbourhoods were not perceived as "social living", neither at the very beginning of their construction nor today, such that these areas do not suffer from a critical lack of green spaces or sport facilities. Thus the built environment was not recognized as playing an important role in the development of child and teenage obesity in the Czech Republic.

Obesity is caused by complex interactions between various genetic and environmental factors. From our study, it is obvious that micro-geographic characteristics (such as the built environment and neighbourhood quality) do not seem to significantly influence the overweight/obesity of the surveyed teenagers, so that the main influences reside in the family environment and individual life-style habits. Public health policies therefore have to focus on individual-, family-, and school-based interventions to promote a healthy life style (Dodson et al., 2009; Kipke et al., 2007; Nestle, 2010; Simon et al., 2008). Parents might be targetted to increase their involvement in their children's leisure time activities, mainly hobbies and physical exercise. Given the extremely low involvement in school physical education revealed in this pilot study, considerable attention should be focused on school environments, their sport facilities and the quality of their physical education courses. Last but not least, after revealing the significant association between family affluence and overweight/obesity, it can be concluded that schools should also have a role in promoting the available physical activities for everybody, including those children whose parents cannot afford to pay for commercial physical activity courses.

\section{Acknowledgements}

The author would like to thank Dr. Ladislav Csémy for his assistance with obtaining data from the elementary schools. This study was supported by the SOPHIE project ("Evaluating the impact of structural policies on health inequalities and their social determinants and fostering change") which received funding from the European Community's Seventh Framework Program (FP7/20072013) under grant agreement No. 278173, and from the Czech Ministry of Health via the grant: "The analysis 
of the relation of youth health risk behaviour and sociodemographical determinants of the environment" (No. 12118-5/2011). This publication was also supported by the project "National Institute of Mental Health (NIMH-CZ)", grant number ED2.1.00/03.0078, and the European Regional Development Fund.

\section{References:}

BLACK, J. L., MACINKO, J. (2008): Neighborhoods and obesity. Nutrition Reviews, 66: 2-20.

BOOTH， K. M., PINKSTON， M. M., POSTON，W. S. C. (2005): Obesity and the built environment. Journal of the American Dietetic Association, 105: 110-117

BROWNSON, R. C., HOEHNER, C. M., DAY, K., FORSYTH, A., SALLIS, J. F. (2009): Measuring the built environment for physical activity: state of the science. American Journal of Preventive Medicine, 36: S99-S123.

COLE, T. J., BELIZZI, M. C., FLEGAL, K. M., DIETZ, W. H. (2000): Establishing a standard definition for child overweight and obesity worldwide: international survey. BMJ, 320: 1-6.

CZECH STATISTICAL OFFICE (2011): Předběžné výsledky sčítání lidu, domů a bytů 2011 [Preliminary results of the Census 2011]. [online] [cit. 25.12.2015] Available at: www.czso.cz.

DAVIS, R., COOK, D., COHEN, L. (2005): A community resilience approach to reducing ethnic and racial disparities in health. American Journal of Public Health, 95: $2188-2173$.

DE VET, E., DE RIDDER, D. T., DE WIT, J. B. (2011): Environmental correlates of physical activity and dietary behaviours among young people: a systematic review of reviews. Obesity Reviews, 12: 130-142.

DING, D., GEBEL, K. (2012): Built environment, physical activity, and obesity: What have we learned from reviewing the literature? Health and Place, 18: 100-105.

DODSON, J. L., HAI, Y., KASAT-SHORS, M., MURRAY, L., NGUYEN, N. K., RICHARDS, A. K., GITTELSOHN, J. (2009): Formative research for a healthy diet intervention among inner-city adolescents: The importance of family, school and neighborhood environment. Ecology of Food and Nutrition, 48: 39-58.

DURAND, C., ANDALIB, M., DUNTON, G., WOLCH, J., PENTZ, M. (2011): A systematic review of built environment factors related to physical activity and obesity risk: implications for smart growth urban planning. Obesity Reviews, 2011: 5 .

DZÚROVÁ, D., CSÉMY, L., SPILKOVÁ, J., LUSTIGOVÁ, M. (2015): Zdravotně rizikové chování mládeže v Česku. Prague, National Institute of Public Health.

ENYEDI, G. (1998): Transformation in Central European postsocialist cities. In: Enyedi, G. [ed.]: Social Change and Urban Restructuring in Central Europe (pp. 9-34). Budapest, Akadémiai Kiadó.

FENG, J., GLASS, T. A., CURRIERO, F. C., STEWART, W. F., SCHWARTZ, B.S. (2010): The built environment and obesity: A systematic review of the epidemiologic evidence. Health and place, 16: 175-190.

FRANZINI, L., ELLIOT, M. N., CUCCARO, P., SCHUSTER, M., GILLILAND, J., GRUNBAUM, J.A., FRANKLIN, F.
TORTOLERO, S. R. (2009): Influences of Physical and Social neighborhood environments on children's physical activity and obesity. American Journal of Public Health, 99: 271-278.

GEBEL, K., BAUMAN, A. E., PETTICREW, M. (2007): The physical environment and physical activity: a critical appraisal of review articles. American Journal of Preventive Medicine, 32: 361-369.

HAINER, V., KUNEŠOVÁ, M., PAŘÍZKOVÁ, J. (1999): Prevalence and causality of obesity in central and eastern Europe. In: Ailhaud, B. and Guy-Grand, B. [eds.]: Progress in Obesity Research (pp. 653-663). London, Libbey.

HERFERT, G., NEUGENBAUER, C. S., SMIGIEL, C. (2013): Living in residential satisfaction? Insights from largescale housing estates in Central and Eastern Europe. Tijdschrift voor economische en sociale geografie, 104: $57-74$.

JANSSEN, I., BOYCE, W. F., SIMPSON, K., PICKETT, E. (2006): Influence of individual- and area-level measures of socioeconomic status on obesity, unhealthy eating, and physical inactivity in Canadian adolescents. American Journal of Clinical Nutrition, 83: 139-145.

KÄHRIK, A., TAMMARU, T. (2010): Soviet prefabricated panel housing estates: Areas of continued social mix or decline? The case of Tallin. Housing Studies, 25: 201-219.

KEYS, A., FIDANZA, F., KARVONEN, M. J., KIMURA, N., TAYLOR, H. L. (2014): Indices of relative weight and obesity. International Journal of Epidemiology, 43: 655-665.

KIPKE, M. D., IVERSON, E., MOORE, D., BOOKER, C., RUELAS, V., PETERS, A. L., KAUFMAN, F. (2007): Food and park environments: Neighborhood-level risks for childhood obesity in east Los Angeles. Journal of Adolescent Health, 40: 325-333.

KOBZOVÁ, J, VIGNEROVÁ, J., BLÁHA P. et al. (2004): The $6^{\text {th }}$ nationwide anthropological survey of children and adolescents in the Czech Republic in 2001. Central European Journal of Public Health, 12: 126-130.

LEGLEYE, S., BECK, F., SPILKA, S., CHAU, N. (2014): Correction of Body-Mass index using body-shape perception and socioeconomic status in adolescent selfreport surveys. PLOS ONE, 9: 1-9.

LOPEZ, R. P. (2007): Neighborhood risk factors for obesity. Obesity, 15: 2111-2119.

MUSIL, J. et al. (1985): Lidé a sídliště. Prague, Svoboda.

MUSIL, J. (1987): Housing policy and the sociospatial structure of cities in a socialist country: the example of Prague. International Journal of Urban and Regional Research, 11: 27-36.

NESTLE, M. (2010): Strategies to prevent childhood obesity must extend beyond school environments. American Journal of Preventive Medicine, 39: 280-281.

O FERDINAND, A., SEN, B., RAHURKAR, S., ENGLER, S., MENACHEMI, N. (2012): The relationship between built environments and physical activity: a systematic review. American Journal of Public Health, 102: 7-13.

PACIONE, M. (2003): Urban environmental quality and human wellbeing - a social geographical perspective. Landscape and Urban Planning, 65: 19-30. 
PANTER, J.R., JONES, A. (2010): Attitudes and the environment as determinants of active travel in adults: what do and don't we know. Journal of Physical Activity Health 7(4): 551-561.

SAELENS， B. E., SALLIS， J. F., FRANK， L. D. (2003): Environmental correlates of walking and cycling: Findings from the transportation, urban design, and planning literatures. Annals of Behavioral Medicine, 25: 80-91.

SAELENS, B. E., SALLIS, J. F., BLACK, J. B., CHEN, D. (2003): Neighborhood-based differences in physical activity: An environment scale evaluation. American Journal of Public Health, 93: 1552-1558.

SIMON, P. A., KWAN, D., ANGELESCU, A., SHIS, M., FIELDING, J.E. (2008): Proximity of fast food restaurants to schools: Do neighborhood income and type of school matter? Preventive medicine, 47: 284-288.

SINGH， G. K., SIAHPUSH，M，KOGAN，M. D. (2010): Neighborhood socioeconomic conditions, built environments, and childhood obesity. Health Affairs, 29: 503-512.
STORY, M., NEUMARK-SZTAINER, D., FRENCH, S. (2002): Individual and environmental influences on adolescent eating behaviors. Journal of the American Dietetic association, 102: S40-S51.

VAN KEMPEN, R., MUSTERD, S., ROWLANDS, R. (2009): Mass Housing in Europe: Multiple Faces of Development, Change and Response. New York, Palgrave Macmillan.

VAN LENTHE, F. J., MACKENBACH, J. P. (2002): Neighborhood deprivation and overweight: the GLOBE study. International Journal of Obesity Related Metabolical Disorders, 26: 234-240.

WEDEN, M. M., CARPIANO, R. M., ROBERT, S. A. (2008): Subjective and objective neighborhood characteristics and adult health. Social Science and Medicine, 66: $1256-1270$.

WINSTANLEY, E. L. et al. (2008): The association of selfreported neighborhood disorganization and social capital with adolescent alcohol and drug use, dependence, and access to treatment. Drug and alcohol dependence, 92: $173-182$.

\section{Please cite this article as:}

SPILKOVÁ, J. (2016): Teenage overweight and obesity: A pilot study of obesogenic and obesoprotective environments in the Czech Republic. Moravian Geographical Reports, 24(1): 55-64. Doi: 10.1515/mgr-2016-0005. 